\title{
Historical and Theoretical Bases of Applied Developmental Science
}

\author{
RiCHARD M. LERNER \\ DONALD WerTLIEB \\ FRANCINE JACOBS
}

$\mathrm{T}$ he latter part of the 20th century was marked by public anxiety about myriad social problems, some old, some new, but all affecting the lives of vulnerable children, adolescents, adults, families, and communities (Fisher \& Murray, 1996; Lerner, 1995; Lerner \& Galambos, 1998; Lerner, Sparks, \& McCubbin, 1999). For instance, in America, a set of problems of historically unprecedented scope and severity involved interrelated issues of economic development, environmental quality, health and health care delivery, poverty, crime, violence, drug and alcohol abuse, unsafe sex, and school failure.

Indeed, in the last years of the 20th century and the first years of the present one, across the United States and in other nations, infants, children, adolescents, and the adults who care for them continued to die from the effects of these social problems (Dryfoos, 1990; Hamburg, 1992; Hernandez, 1993; Huston, 1991; Lerner, 1995; Lerner \& Fisher, 1994; Schorr, 1988, 1997). And if people were not dying, their prospects for future success were being reduced by civil unrest and ethnic conflict, by famine, by environmental challenges (e.g., involving water quality and solidwaste management), by school underachievement and dropping out, by teenage pregnancy and parenting, by lack of job opportunities and preparedness, by prolonged welfare dependency, by challenges to their health (e.g., lack of immunization, inadequate screening for disabilities, insufficient prenatal care, and lack of sufficient infant and childhood medical services), and by the sequelae of persistent and pervasive poverty (Dryfoos, 1990; Huston, 1991; Huston, McLoyd, \& Garcia Coll, 1994; Lerner, 1995; Lerner et al., 1999; Lerner \& 
Fisher, 1994). These issues challenge the resources and the future viability of civil society in America and throughout the world (Lerner, Fisher, \& Weinberg, 2000a, 2000b).

The potential role of scientific knowledge about human development in addressing these issues of individuals, families, communities, and civil society has resulted in growing interest and activity in what has been termed applied developmental science (ADS). Indeed, over the last two decades, increasing numbers of developmental scientists from diverse disciplines have come to identify themselves professionally as applied developmental scientists. Joining under this umbrella are colleagues from allied disciplines and specialties in the biological, psychological, social, and behavioral sciences and the helping professions, all sharing common goals and visions captured in some of the more formal definitions of the ADS field.

In many ways, ADS is "old wine in a new bottle"; that is, significant historical antecedents to the burgeoning field are evident today (Wertlieb, 2003). It is useful here to provide a brief overview of this history, focusing most on the events over the last quarter of a century that have given shape to contemporary ADS.

\section{APPLIED DEVELOPMENTAL SCIENCE: A BRIEF HISTORY}

ADS has its roots in numerous fields concerned with human development, for example, home economics/family and consumer sciences (Meszaros, 2003; Nickols, 2002), human ecology (Bronfenbrenner \& Morris, 1998), comparative psychology (Tobach, 1994), and developmental psychology (Wertlieb, 2003). Using the latter field as a sample case, we may note that several extensive histories of developmental psychology have been published and most include references to the ebb and flow of interest and priority for what might be termed the applied, practical, or societally oriented issues central to ADS. Especially relevant are discussions offered by Bronfenbrenner, Kessel, Kessen, and White (1986); Cairns (1998); Davidson and Benjamin (1987); Hetherington (1998); McCall (1996); McCall and Groark (2000); Sears (1975); Siegel and White (1982); Parke, Ornstein, Reiser, and Zahn-Waxler (1994), Zigler (1998); and Zigler and Finn-Stevenson (1992, 1999). Hetherington (1998) frames her analysis by accenting her use of the term "developmental science... to emphasize both the scientific and multidisciplinary foundations of the study of development and the recognition that development is not confined to childhood but extends across the life span" (p. 93), an emphasis that is lost or diluted in the too-limiting term child psychology. Hetherington interprets and extends Sears's (1975) classic analysis, reaffirming that "unlike many areas in psychology [with their histories documented by Boring (1950) and Koch \& Leary (1985)], developmental science originated from the need to solve practical problems and evolved from pressure to improve the education, health, welfare and legal status of children and their families" (p. 93).

The chronology of developmental psychology offered by Cairns (1998) serves as a useful framework within which to specify some of the distinctive or seminal elements of ADS. Cairns segments the emergence of developmental psychology (1882-1912), the middle period of institutionalization and expansion (1913-1946), and the modern era (1947-1976). His compliance with a convention that 20 years must elapse before qualifying as "historical" leaves much of 
the significant milestone material in the defining of ADS, to be mentioned below, outside the realm of his presentation, although he does conclude his account with a clarion anticipation of and call for more integrated interdisciplinary science, quite consistent with what we might term the postmodern or contemporary era (1977 to the present). Indeed, it will be from this most recent period that we draw our substantive examples of ADS, after the conclusion of this historical sketch.

Most accounts, including Cairn's (1998) "emergence" analysis, portray the dialectic at the base of ADS as pioneered by G. Stanley Hall, the first professor of psychology in America (appointed in 1883 at Johns Hopkins University), the first president of the American Psychological Association (1891), and founder of the first child development research institute at Clark University and of the journal, Pedagogical Seminary.

Hall was a remarkable teacher and catalyst for the field. Some of the most significant areas for developmental study-mental testing, child study, early education, adolescence, life span psychology, evolutionary influence on development-were stimulated or anticipated by Hall. Because of shortcomings in the methods he employed and the theory he endorsed, few investigators stepped forward to claim Hall as a scientific mentor. His reach exceeded his grasp in the plan to apply the principles of the new science to society. Psychology's principles were too modest, and society's problems too large. Perhaps we should use a fresh accounting to judge Hall's contributions, one that takes into account the multiple facets of his influence on individuals, the discipline, and society. The audit would reveal that all of us who aspire to better the lot of children and adolescents can claim him as a mentor. (Cairns, 1998, p. 43)

White (1992) points to the work of Bronfenbrenner as being consistent with his own perspective. For instance, Bronfenbrenner et al. (1986) noted,

The simple fact is that G. Stanley Hall marched away from experimental psychology toward the study of children because at least six different constituencies existed in American society, basically still our constituencies today-scientists, college administrators, child savers and social workers, mental health workers, teachers, and parents. These constituencies wanted certain kinds of knowledge about children. Mirabile dictu, without even being developmental psychologists and before we came into existence, they were all collecting data that look like ours. So, if you look at the social history that surrounds the birth of the Child Study Movement, you gradually come to the conclusion that perhaps we represent a professionalization of trends of knowledge gathering and knowledge analysis that existed in our society before our coming. That doesn't completely detach us from the mainstream of the history of psychology, but it certainly throws a very different light on the emergence and evolution of the field and its basic issues. (p. 1221)

Among Hall's most significant contributions, according to White (1992), were the concern with descriptions of children in their natural contexts and the priority need "to arrive at a scientific synthesis on the one side and practical recommendations on the other" (as cited in Cairns, 1998, p. 43). Contemporary ADS continues in its value in the former and aspires to overcome the too-dichotomous implications of the second; it emphasizes the reciprocal and mutual interactions of the scientific and practical that were typical in this earliest era.

Within the last quarter of a century, a key milestone in the elaboration of the field's territory occurred with the founding of the Journal of Applied Developmental Psychology, in 1980, an international multidisciplinary life span journal. The masthead proclaimed: 
A forum for communication between researchers and practitioners working in life span human development fields, a forum for the presentation of the conceptual, methodological, policy, and related issues involved in the application of behavioral science research in developmental psychology to social action and social problem solving. (Sigel \& Cocking, 1980, p. i)

In welcoming the new journal in an inaugural editorial, Zigler (1980) narrowed the definition of the journal's purview to what he called a "field within a field" (i.e., presumably, applied developmental psychology within developmental psychology) but set high and broad expectations that "these pages shall attest to the synergistic relationship between basic and applied research" (p. 1).

Almost 20 years later, Zigler (1998) issued a similar note of hope, celebration, and welcome in a significant essay called "A Place of Value for Applied and Policy Studies," this time in the pages of Child Development, the prestigious archival journal of the Society for Research in Child Development (SRCD). Child Development had been singularly devoted to ...

Theory-driven, basic research. Now, after more than six decades of advancing science as a means to expand our understanding of human development, SRCD has formally welcomed into its major journal research that uses this knowledge on children's behalf ... the result of a very gradual transformation within SRCD from a scientist's science toward a more public science. (Zigler, 1998, p. 532)

The continuing vicissitudes of the gaps and synergies between applied and basic research will be a theme of the historical sketch offered below (see also Garner, 1972).

In 1991, the National Task Force on Applied Developmental Science convened representatives from a broad, but not exhaustive, range of professional scientific organizations concerned with the application of the developmental psychology knowledge base to societal problems. Organizations represented included the American Psychological Association (APA), the Gerontological Society of America, the International Society for Infant Studies, the National Black Child Development Institute, the National Council on Family Relations, the Society for Research on Adolescence, and the Society for Research in Child Development. Goals included the articulation of the definition and scope of ADS along with guidelines for graduate training in this emergent interdisciplinary field. A consensus process produced a complex fourpoint definition of ADS, quoted here at length to document the current parameters of content, process, methods, and values:

1.1. Applied developmental science involves the programmatic synthesis of research and applications to describe, explain, intervene, and provide preventive and enhancing uses of knowledge about human development. The conceptual bases of ADS reflects the view that individual and family functioning is a combined and interactive product of biology and the physical and social environments that continuously evolve and change over time. ADS emphasizes the nature of reciprocal person-environment interactions among people, across settings, and within a multidisciplinary approach stressing individual and cultural diversity. This orientation is defined by three conjoint emphases:

Applied: Direct implications for what individuals, families, practitioners, and policymakers do.

Developmental: Systematic and successive changes within human systems that occur across the life span.

Science: Grounded in a range of research methods designed to collect reliable and objective information systematically that 
can be used to test the validity of theory and application.

1.2. ADS recognizes that valid applications of our knowledge of human development depend on scientifically based understanding of multilevel normative and atypical processes that continually change and emerge over the life cycle.

1.3. ADS reflects an integration of perspectives from relevant biological, social, and behavioral sciences disciplines in the service of promoting development in various populations.

1.4. The nature of work in ADS is reciprocal in that science drives application and application drives science. ADS emphasizes the bidirectional relationship between those who generate empirically based knowledge about developmental phenomena and those who pursue professional practices, services, and policies that affect the well-being of members of society. Accordingly, research and theory guide intervention strategies, and evaluations of outcomes of developmental interventions provide the basis for the reformulation of theory and for modification of future interventions. (Fisher et al., 1993, pp. 4-5)

By 1997, these parameters defining ADS were adopted as the editorial scope of a new journal, Applied Developmental Science, with further explication of a more inclusive range of methodologies and audiences. According to Lerner, Fisher, and Weinberg (1997), the journal publishes ...

Research employing any of a diverse array of methodologies-multivariate longitudinal studies, demographic analyses, evaluation research, intensive measurement studies, ethnographic analyses, laboratory experiments, analyses of policy and/or policy-engagement studies, or animal comparative studies-when they have important implications for the application of developmental science across the life span. Manuscripts pertinent to the diversity of development throughout the life spancross-national and cross-cultural studies; systematic studies of psychopathology; and studies pertinent to gender, ethnic and racial diversity—are particularly welcome. ... (The audience includes) developmental, clinical, school, counseling, aging, educational, and community psychologists; life course, family and demographic sociologists; health professionals; family and consumer scientists; human evolution and ecological biologists; practitioners in child and youth governmental and nongovernmental organizations. (p. 1)

This amplified definition of ADS postulates a number of hallmarks of ADS key to the discussion of its history, content, and special concerns. Among these hallmarks are the following:

1. A historical context and perspective reflecting the perennial balancing of related constructs such as basic and applied research or science and practice or knowledge generation and use. This includes a sensitivity to historical and sociopolitical contexts captured in the notion of ADS as ...

Scholarship for our times.... As we enter the 21st century, there is growing recognition that traditional and artificial distinctions between science and service and between knowledge generation and knowledge application need to be reconceptualized if society is to successfully address the harrowing developmental sequelae of the social, economic and geo-political legacies of the 20th century. Scholars, practitioners and policymakers are increasingly recognizing the role that developmental science can play in stemming the tide of life chance destruction caused by poverty, premature births, school failure, child abuse, crime, adolescent pregnancy, substance abuse, unemployment, welfare dependency, discrimination, ethnic conflict, and inadequate health and social resources. (Lerner et al., 1997, p. 2) 


\section{A broadened and deepened awareness} of the ethical challenges and imperatives involved in implementing the scope of ADS. This awareness evolves from challenges in the use of scientific methods in new ways such that protection of the autonomy and well-being of participants is increasingly complex. Research participants become partners in the inquiry process and new, more complicated collaborations among diverse multidisciplinary professionals and communities become key elements of defining research questions and problems and seeking answers and solutions.

Moreover, as implied earlier in the chapter, some leaders of ADS have seen the need to further broaden the potential scope of this field, suggesting elements of a blueprint for promoting civil society and social justice, a provocative and compelling elaboration of both the substance and ethical orientation of the field (Lerner et al., 2000b). Others have focused on more traditional, academic, or incremental stocktaking for defining ADS, with attention to advancing the numerous knowledge bases and methodologies (e.g., Schwebel, Plumert, \& Pick, 2000; Shonkoff, 2000; Sigel \& Renninger, 1998). However, given the presence of this range of interests and activities, ADS is now considered "an established discipline" (Fisher, Murray, \& Sigel, 1996), one that is operationalized by the diverse foci of work pursued under this framework but is linked by a common conceptual/theoretical perspective about human development: developmental systems theory. To understand the diversity of empirical, methodological, and ethical interests and activities of contemporary ADS, it is important to appreciate the developmental systems theoretical orientation that rationalizes the use of developmental science for the promotion of positive human development and the enhancement of civil society.

\section{FROM DEVELOPMENTAL SYSTEMS THEORIES TO APPLIED DEVELOPMENTAL SCIENCE}

Paul Mussen, the editor of the third edition of the Handbook of Child Psychology, presaged what today is abundantly clear about the contemporary stress on systems theories of human development. Mussen (1970) said, "The major contemporary empirical and theoretical emphases in the field of developmental psychology... seem to be on explanations of the psychological changes that occur, the mechanisms and processes accounting for growth and development" (p. vii). This vision alerted developmental scientists to a burgeoning interest-not in structure, function, or content per se, but in change, in the processes through which change occurs, and in the means through which structures transform and functions evolve over the course of human life.

Today, Mussen's (1970) vision has been crystallized. The cutting edge of contemporary developmental theory is represented by systems conceptions of the process of how structures function and how functions are structured over time. Thus, developmental systems theories of human development are not necessarily tied to a particular content domain, although particular empirical issues or substantive foci (e.g., motor development, successful aging, wisdom, extraordinary cognitive achievements, language acquisition, the self, psychological complexity, or concept formation) may lend themselves readily as exemplary sample cases of the processes depicted in a given theory (see Lerner, 1998a).

The power of developmental systems theories lies in their ability to not be limited or confounded by an inextricable association with a unidimensional portrayal of the developing person. In developmental systems theories, the person is neither biologized, psychologized, nor sociologized. Rather, 
the individual is systemized. A person's development is embedded within an integrated matrix of variables derived from multiple levels of organization. Development is conceptualized as deriving from the dynamic relations among the variables within this multitiered matrix.

Developmental systems theories use the polarities that engaged developmental theory in the past (e.g., nature/nurture, individual/ society, biology/culture; Lerner, 1976, 1986, 2002b). They are not used to "split" depictions of developmental processes along conceptually implausible and empirically counterfactual lines (Gollin, 1981; Overton, 1998) or to force counterproductive choices between false opposites (e.g., heredity or environment, continuity or discontinuity, constancy or change; Lerner, 2002b), but rather to gain insight into the integrations that exist among the multiple levels of organization involved in human development. These theories are certainly more complex than their one-sided predecessors. They are also more nuanced, more flexible, more balanced, and less susceptible to extravagant or even absurd claims: for instance, that nature split from nurture can shape the course of human development; that there is a gene for altruism, militarism, or intelligence; or that when the social context is demonstrated to affect development, the influence can be reduced to a genetic one (e.g., Hamburger, 1957; Lorenz, 1966; Plomin, 1986, 2000; Plomin, Corley, DeFries, \& Faulker, 1990; Rowe, 1994; Rushton, 1987, 1988a, 1988b, 1997, 1999).

These mechanistic and atomistic views of the past have been replaced, then, by theoretical models that stress the dynamic synthesis of multiple levels of analysis, a perspective having its roots in systems theories of biological development (Cairns, 1998; Gottlieb, 1992; Kuo, 1930, 1967, 1976; Schneirla, 1956, 1957; von Bertalanffy, 1933). In other words, development, understood as a property of systemic change in the multiple and integrated levels of organization comprising human life and its ecology (ranging from biology to culture and history), is an overarching conceptual frame associated with developmental systems models of human development.

\section{Explanation and Application: A Synthesis}

This stress on the dynamic relation between the individual and his or her context results in the recognition that a synthesis of perspectives from multiple disciplines is needed to understand the multilevel integrations involved in human development. In addition, to understand the basic process of human development, both descriptive and explanatory research must be conducted within the actual ecology of people's lives.

Explanatory studies, by their very nature, constitute intervention research. The role of the developmental researcher conducting explanatory research is to understand the ways in which variations in person-context relations account for the character of human developmental trajectories, life paths that are enacted in the natural laboratory of the real world. To gain an understanding of how theoretically relevant variations in personcontext relations may influence developmental trajectories, the researcher may introduce policies and/or programs as experimental manipulations of the proximal and/or distal natural ecology. Evaluations of the outcomes of such interventions become a means to bring data to bear on theoretical issues pertinent to person-context relations. More specifically, these interventions have helped applied developmental scientists understand the plasticity in human development that may exist and that may be capitalized on to enhance human life (Csikszentmihalyi \& Rathunde, 1998; Lerner, 1984). 
The interindividual differences in intraindividual change that exist as a consequence of these naturally occurring interventions attest to the magnitude of the systematic changes in structure and function-the plasticity-that characterizes human life. Explanatory research is necessary, however, to understand which variables, from which levels of organization are involved in particular instances of plasticity that have been seen to exist. In addition, such research is necessary to determine which instances of plasticity may be created by science or society. In other words, explanatory research is needed to ascertain the extent of human plasticity or in turn, to test the limits of plasticity (Baltes, 1987; Baltes, Lindenberger, \& Staudinger, 1998; Lerner, 1984).

From a developmental systems perspective, the conduct of such research may lead the scientist to alter the natural ecology of the person or group he or she is studying. Such research may involve either proximal and/or distal variations in the context of human development (Lerner \& Ryff, 1978); but in any case, these manipulations constitute theoretically guided alterations of the roles and events a person or group experiences at, or over, a portion of the life span.

These alterations are indeed, then, interventions: They are planned attempts to alter the system of person-context relations that constitute the basic process of change; they are conducted to ascertain the specific bases of or to test the limits of particular instances of human plasticity (Baltes, 1987; Baltes \& Baltes, 1980; Baltes et al., 1998). These interventions are a researcher's attempt to substitute designed person-context relations for naturally occurring ones in an attempt to understand the process of changing person-context relations that provides the basis of human development. In short, then, basic research in human development is intervention research (Lerner et al., 1994).

Accordingly, the cutting edge of theory and research in human development lies in the application of the conceptual and methodological expertise of human developmental scientists to the natural ontogenetic laboratory of the real world. This placement of explanatory research about the basic relational process of development into the actual ecology of human development, then, involves the fusion of application with basic developmental science. To pursue the study of ontogeny from a developmental systems perspective, a research/application agenda that focuses on the relations between diverse individuals and their similarly diverse contexts is brought to the forefront (Lerner, $2002 \mathrm{~b})$. In addition, however, scholars involved in such research must have at least two other concerns deriving from the view that basic explanatory research in human development is, in its essence, intervention research.

Research in human development that is concerned with one or even a few instances of individual and contextual diversity cannot be assumed to be useful for understanding the life courses of all people. Similarly, policies and programs derived from such research or associated with it in the context of a researcher's tests of ideas pertinent to human plasticity cannot hope to be applicable or equally appropriate and useful in all contexts or for all individuals. Accordingly, policy development and program (intervention) design and delivery that are developmental and oriented to individual differences must be a key part of the approach to applied developmental research for which we are calling.

The variation in settings within which people live means that studying development in a standard (for example, a controlled) 
environment does not provide information pertinent to the actual (ecologically valid) developing relations between individually distinct people and their specific contexts (for example, their particular families, schools, or communities). This point underscores the need to conduct research in real-world settings (Bronfenbrenner, 1974; Zigler, 1998) and highlights the ideas that (a) policies and programs constitute natural experiments, that is, planned interventions for people and institutions, and (b) the evaluation of such activities becomes a central focus in the developmental systems research agenda we have described (Cairns, Bergman, \& Kagan, 1998; Lerner, 1995; Lerner, Ostrom, \& Freel, 1995; Ostrom, Lerner, \& Freel, 1995).

In this view, then, policy and program endeavors do not constitute secondary work or derivative applications conducted after research evidence has been complied. Quite to the contrary, policy development and implementation and program design and delivery become integral components of the ADS approach to research; the evaluation component of such policy and intervention work provides critical feedback about the adequacy of the conceptual frame from which this research agenda should derive (Zigler, 1998; Zigler \& Finn-Stevenson, 1992).

In essence, then, a developmental systems perspective leads us to recognize that if we are to have an adequate and sufficient science of human development, we must integratively study individual and contextual levels of organization in a relational and temporal manner (Bronfenbrenner, 1974; Zigler, 1998). We may also seek to serve America's citizens and families through our science and help develop successful policies and programs through our scholarly efforts that result in the promotion of positive human development. To do this, we may make great use of the integrative, temporal, and relational model of the person and of his or her context that is embodied in developmental system theories of human development.

\section{From Developmental Systems Theory to the Core Principles of ADS}

As has been argued before us-for example, by Fisher (e.g., Fisher et al., 1993; Fisher \& Lerner, 1994); Weinberg (e.g., Lerner et al., 1997, 2000a, 2000b); Sherrod (e.g., 1999a, 1999b); Eccles (Eccles, Lord, \& Buchanan, 1996); Takanishi (1993); Lerner (Lerner, 1998b, 2002a, 2002b); and Wertlieb (2003)_ADS is scholarship predicated on a developmental systems theoretical perspective. Within this context, Fisher et al. (1993) summarize the five conceptual components that together characterize the core principles of ADS. Taken together, these conceptual principles make ADS a unique approach to understanding and promoting positive development.

The first conceptual component of ADS is the notion of the temporality, or historical embeddedness, of change pertinent to individuals, families, institutions, and communities. Some components of the context or of individuals remain stable over time, and other components may change historically. Because phenomena of human behavior and development vary historically, one must assess whether generalizations across time periods are legitimate. Thus, temporality has important implications for research design, service provision, and program evaluation.

Interventions are aimed at altering the developmental trajectory of within-person changes. To accomplish this aim, the second conceptual feature of ADS is that applied developmental scientists take into account 
interindividual differences (diversity) among, for instance, racial, ethnic, social class, and gender groups, and intraindividual changes, such as those associated with puberty.

The third conceptual feature of ADS places an emphasis on the centrality of context. There is a focus on the relations among all levels of organization within the ecology of human development. These levels involve biology, families, peer groups, schools, businesses, neighborhoods and communities, physical/ecological settings, and the sociocultural, political, legal, moral, and economic institutions of society. Together, bidirectional relations among these levels of the developmental system necessitate systemic approaches to research, program and policy design, and program and policy implementation.

The fourth principle of ADS emphasizes descriptively normative developmental processes and primary prevention and optimization, rather than remediation. Applied developmental scientists emphasize healthy and normative developmental processes and seek to identify the strengths and assets of individuals, groups, and settings, rather than focusing on deficits, weaknesses, or problems of individuals, families, or communities. Instead of dwelling on the problems faced by people, applied developmental scientists aim to find combinations of individual and ecological assets associated with thriving among people (e.g., Benson, 1997; Benson, Leffert, Scales, \& Blyth, 1998; Leffert et al., 1998; Scales, Benson, Leffert, \& Blyth, 2000) and with the " $5 \mathrm{Cs}$ " of positive individual development: competence, confidence, connection, character, and caring/compassion (Hamilton \& Hamilton, 1999; Lerner, 2002b; Little, 1993; Pittman, 1996).

The final principle of ADS is the appreciation of the bidirectional relationship between knowledge generation and knowledge application. By acknowledging bidirectionality, applied developmental scientists recognize the importance of knowledge about life and development that exists among the individuals, families, and communities being served by ADS. For applied developmental scien-tists, collaboration and colearning between researchers/universities and communities are essential features of the scholarly enterprise (Lerner, 1998a, 1998b). Such community-collaborative efforts are termed outreach scholarship (Lerner \& Miller, 1998).

In other words, given the developmental systems perspective on which ADS is predicated, applied developmental scientists assume the following:

There is an interactive relationship between science and application. Accordingly, the work of those who generate empirically based knowledge about development and those who provide professional services or construct policies affecting individuals and families is seen as reciprocal in that research and theory guide intervention strategies and the evaluation of interventions and policies provides the bases for reformulating theory and future research.... As a result, applied developmental [scientists] not only disseminate information about development to parents, professionals, and policymakers working to enhance the development of others, they also integrate the perspectives and experiences of these members of the community into the reformulation of theory and the design of research and interventions. (Fisher \& Lerner, 1994, p. 7)

Given the theoretically predicated set of principles defining ADS, it is clear that not all possible realms of developmental science would lend themselves to this view of scholarship (e.g., genetic-reductionist approaches to human development would not fit within this approach; for a more thorough discussion of this point, see Lerner, 2002b). It is useful, then, to discuss the dimensions of scientific work that are brought to the forefront by an ADS perspective framed by developmental systems thinking. 


\section{FOCI OF APPLIED DEVELOPMENTAL SCIENCE}

Human developmental science has long been associated with laboratory-based scholarship devoted to uncovering "universal" aspects of development by stripping away contextual influences (Cairns et al., 1998; Hagen, 1996). However, the mission and methods of human development are being transformed into an ADS that is devoted to discovering diverse developmental patterns by examining the dynamic relations between individuals within the multiple embedded contexts of the integrated developmental systems in which they live (Fisher \& Brennan, 1992; Fisher \& Lerner, 1994; Fisher \& Murray, 1996; Horowitz, 2000; Horowitz \& O'Brien, 1989; Lerner, 1998a, 1998b, 2002a, 2002b; Lerner et al., 2000a, 2000b; Morrison, Lord, \& Keating, 1984; Power, Higgins, \& Kohlberg, 1989; Sigel, 1985). This theoretical revision of the target of developmental analysis, from the elements of relations to interlevel relations, has significant implications for applications of developmental science to policies and programs aimed at promoting positive human development. Arguably, the most radical feature of the theoretical, research, and applied agenda of applied developmental scientists is the idea that research about basic relational processes of development and applications focused on enhancing person-context relations across ontogeny are one and the same endeavor. Within this synthetic approach to basic and applied scholarship, several specific domains of scholarship are pursued by applied developmental scientists.

The National Task Force on Applied Developmental Science (Fisher et al., 1993) indicates that the activities of ADS span a continuum from knowledge generation to knowledge application (see also Wertlieb, 2003). These activities include, but are not limited to, the following: research on the applicability of scientific theory to growth and development in natural, ecologically valid contexts; the study of developmental correlates of phenomena of social import; the construction and use of developmentally and contextually sensitive assessment instruments; the design and evaluation of developmental interventions and enhancement programs; and the dissemination of developmental knowledge to individuals, families, communities, practitioners, and policymakers through developmental education, printed and electronic materials, the mass media, expert testimony, and community collaborations.

To illustrate, Table 1.1 lists many of the topics of inquiry and action that are recurrently part of the broad scope of ADS. Recent textbooks (e.g., Fisher \& Lerner, 1994); review chapters (e.g., Zigler \& Finn-Stevenson, 1999); handbooks; (e.g., Lerner, 2002a, 2002b; Sigel \& Renninger, 1998); special issues of journals (e.g., Hetherington, 1998); and regular sections of journals, such as the "Applied Developmental Theory" section of Infants and Young Children, provide ongoing articulation of ADS inquiry. Journals such as the Journal of Applied Developmental Psychology, Applied Developmental Science, and Children's Services: Social Policy, Research and Practice are among the central outlets for new work in ADS.

\section{Applied Developmental Science and the Concept of Outreach Scholarship}

Given (a) their belief in the importance for developmental analysis of systemically integrating all components within the ecology of human development and (b) their stress on integrating the expertise of the researcher with the expertise of the community through collaboration and colearning, 
Table 1.1 Areas of Inquiry and Action in Applied Developmental Science

\begin{tabular}{ll}
\hline Topic & Sample Study or Review \\
\hline Early child care and education & $\begin{array}{l}\text { Lamb (1998); Scarr (1998); Zigler \& Finn-Stevenson (1999); } \\
\text { Ramey \& Ramey (1998) }\end{array}$ \\
Early childhood education & Elkind (2002) \\
Education reform and schooling & $\begin{array}{l}\text { Fishman (1999); Adelman \& Taylor (2000); } \\
\text { Renninger (1998); Strauss (1998) }\end{array}$ \\
Literacy & Adams, Trieman, \& Pressley (1998); \\
Parenting and parent education & Collins, Maccoby, Steinberg, Hetherington, \& Bornstein \\
Poverty & (2000); Cowan, Powell, \& Cowan (1998) \\
Developmental assets & McLoyd (1998); Black \& Krishnakumar (1998) \\
Successful children and families & Greenberg (1998) \\
Marital disruption and divorce & Masten \& Coatsworth (1998); Wertlieb (2001) \\
Developmental psychopathology & Wertlieb (1997); Hetherington, Bridges, \& Insabella (1998) \\
Richters (1997); Cicchetti \& Sroufe (2000); Rutter \& & Sroufe (2000); Cicchetti \& Toth (1998b) \\
Depression & Cicchetti \& Toth (1998a) \\
Domestic violence and maltreatment & Emery \& Laumann-Billings (1998) \\
Adolescent pregnancy & Coley \& Chase-Landsdale (1998) \\
Aggression and violence & Loeber \& Stouthamer-Loebe (1998) \\
Children's eyewitness reports & Bruck, Ceci, \& Hembrooke (1998) \\
Pediatric psychology & Bearison (1998) \\
Mass media, television, and computers & Huston \& Wright (1998); Martland \& Rothbaum (1999) \\
& Kaplan (2000); Coie et al. (1993) \\
\hline &
\end{tabular}

proponents of ADS believe that researchers and the institutions within which they work are part of the developmental system that ADS tries to understand and to enhance. They emphasize that the scholar- and university-community partnerships they seek to enact are an essential means of contextualizing knowledge. By embedding scholarship about human development within the diverse ecological settings in which people develop, applied developmental scientists foster bidirectional relationships between research and practice. Within such relationships, developmental research both guides and is guided by the outcomes of community-based interventions, for example, public policies or programs aimed at enhancing human development. 
The growth of such outreach scholarship (Lerner \& Miller, 1998) has fostered a scholarly challenge to prior conceptions of the nature of the world (Cairns et al., 1998; Overton, W., 1998; Valsiner, 1998). The idea that all knowledge is related to its context has promoted a change in the typical ontology within current scholarship. This change has emerged as a focus on relationism and an avoidance of split conceptions of reality, such as nature versus nurture (Overton, W., 1998). This ontological change has helped advance the view that all existence is contingent on the specifics of the physical and social cultural conditions that exist at a particular moment of history (Overton, 1998; Pepper, 1942). Changes in epistemology that have been associated with this revision in ontology and contingent knowledge can be understood only if relationships are studied.

Accordingly, any instance of knowledge (e.g., the core knowledge of a given discipline) must be integrated with knowledge of (a) the context surrounding it and (b) the relation between knowledge and context. Thus, knowledge that is disembedded from the context is not basic knowledge. Rather, knowledge that is relational to its context, for example, to the community as it exists in its ecologically valid setting (Trickett, Barone, \& Buchanan, 1996), is basic knowledge. Having an ontology of knowledge as ecologically embedded and contingent rationalizes the interest of ADS scholars in learning to integrate what they know with what is known of and by the context (Fisher, 1997). It thus underscores the importance of colearning collaborations between scholars and community members as a key part of the knowledge generation process (HigginsD’Alessandro, Fisher, \& Hamilton, 1998; Lerner \& Simon, 1998a, 1998b).

In sum, significant changes that have occurred in the way social and behavioral scientists-and more specifically, human developmentalists-have begun to reconceptualize their roles and responsibilities to society is in no greater evidence than in the field of ADS (Fisher \& Murray, 1996; Lerner, 2002a, 2002b; Lerner et al., 2000a, $2000 \mathrm{~b})$. However, the key test of the usefulness of the integrative relational ideas of applied developmental scientists lies in a demonstration of the greater advantages for understanding and application of a synthetic focus on person-context relations-as compared with an approach to developmental analysis predicated on splitting individuals from their contexts or splitting any level within the developmental system from another, for example, splitting biological from individual/psychological or social levels through genetic reductionism (e.g., as in Rowe, 1994; Rushton, 1999, 2000). In other words, can we improve our understanding of human development and enhance our ability to promote positive outcomes of changes across life by adopting the relational approach of an ADS predicated on developmental systems thinking?

\section{THE PLAN OF THIS TEXT}

We believe the answer to this question is "yes," and to support our position, in this text we present scholarship that illustrates how a focus on the person-context relation may enhance understanding of the character of human development and also of the ways in which applications linking persons and contexts in positive ways can enhance human development across the life span. The scholarship represented in this text considers the importance of understanding the match, congruence, quality of fit, or integration between attributes of individuals and characteristics of their contexts in understanding and promoting healthy, positive human development. 


\section{Key Themes of the Text}

Throughout this book, a central theme in current ADS is underscored: the need to develop policies and programs that appropriately treat the bidirectional (or, in other terms, reciprocal, dynamic, or systemic) relations between diverse individuals and their diverse contexts. In addition, the chapters in this volume highlight another level of relation that is central in understanding the distinct developmental trajectories involved in diverse person-context relations. This level is the bidirectional linkage that exists between theory and application. Throughout the volume, authors explain how a developmental systems view of youth development is both a product and a producer of an integrated understanding of the theory $\leftarrow \rightarrow$ application relation involved in the promotion of positive youth development.

The developmental systems perspective also has implications for the methods and ethics of ADS. Ideas about methods and ethics are also thematic dimensions of the chapters in this volume. It is important to discuss the role of these themes in current and future work in ADS.

\section{METHODOLOGICAL AND ETHICAL DIMENSIONS OF ADS}

In addition to the developmental systems theoretical orientation framing, the substantive domain of scholarship included in this volume and also found more broadly in ADS, we must emphasize that other features of scholarship are emblematic of ADS. That is, specific views of methodology and of ethics are involved in this field of work. As we have noted earlier in this chapter, the empirical parameters of ADS are addressed only to a limited extent by traditional research methods and designs.
Acknowledgment of the conceptual complexity imposed by the relevant developmental contextual and bioecological theories engages increasingly sophisticated methodological approaches. Orchestration of a researcher's perspectives on a set of problems with a society's perspectives on the problem-be they concerns about how to provide a type of care for children or how to sustain the health and development of an ill childrequires extension and innovation by the applied developmental scientist. Some of the extension and innovation is relatively incremental.

For example, the study of children's adaptation to illness becomes the province of interdisciplinary teams of pediatricians, pediatric psychologists, nurses, and child psychiatrists. Bolder innovation advances ADS when (a) families and communities are recognized and embraced as legitimate partners in the research enterprise, (b) the audience or "consumer" of research is broadened to include service providers and policymakers, and (c) traditional institutional structures and functions associated with the "ivory tower" of the university are challenged or modified. A leading perspective in capturing these extensions and innovations is, as previously mentioned, termed outreach scholarship (Chibucos \& Lerner, 1999; Lerner \& Miller, 1998).

Jensen, Hoagwood, and Trickett (1999) contrast university-based research, traditionally supported by the National Institute of Health in an efficacy model, with an outreach model that reflects emergent approaches to research consistent with the parameters of ADS and basic to advancement in the numerous domains of inquiry and action listed in Table 1.1. Outreach research or outreach scholarship characterizes the "engaged university" (Kellogg Commission, 1999) more so than the traditional "ivory tower" university (e.g., McCall, Groark, Strauss \& Johnson, 1995). In outreach scholarship, knowledge 
advances as a function of collaborations and partnerships between universities and communities such that scientists and the children, families, and communities they seek to understand and help are defining problems, methods, and solutions together. Communities include policymakers as well as the families and service providers, who both implement and consume interventions and programs. Lerner et al. (2000b) properly note that this involves a "sea change in the way scholars conduct their research" (p. 14) and then note the principles of outreach scholarship that characterize these special collaborations and methods in ADS. These principles include the following:

(1) An enhanced focus on external validity, on the pertinence of the research to the actual ecology of human development $\ldots$ as opposed to contrived, albeit welldesigned, laboratory type studies; (2) incorporating the values and needs of community collaborators within research activities; (3) full conceptualization and assessment of outcomes, that is, a commitment to understanding thoroughly both the direct and indirect effects of a researchbased intervention program on youth and their context and to measuring these outcomes; (4) flexibility to fit local needs and circumstances, that is, an orientation to adjust the design or procedures ... to the vicissitudes of the community within which the work is enacted; (5) accordingly, a willingness to make modifications to research methods in order to fit the circumstances of the local community; and (6) the embracing of long-term perspectives, that is the commitment of the university to remain in the community for a time period sufficient to see the realization of community-valued developmental goals for its youth... [and in addition] co-learning (between two expert systems-the community and the university); humility on the part of the university and its faculty, so that true colearning and collaboration among equals can occur; and cultural integration, so that both the university and the community can appreciate each other's perspective. (Lerner et al., 2000b, p. 14)
As articulated in the definitional parameters of ADS that opened this chapter and as reflected in the specific examples of inquiry and action, the extensions and innovations involved in outreach scholarship provide a means to address the conceptual and methodological challenges inherent in attending to the synergy and advancement of science and practice. Along with these tools and potentials come a series of ethical imperatives reflecting responsibilities of both researchers and practitioners. These complex challenges have been a central concern to ADS from its earliest contemporary renditions, with the frameworks offered by Fisher and Tryon (1990) continuing to serve well as an agenda.

Fisher and Tryon (1990) noted that along with the synergy and integration of research and application basic to the advance of the field, the applied developmental scientist is bound by the ethics of research, by the ethics of professional service, and by a complicated admixture that emerges with the acknowledgment of their interdependence. In addition, as the notion of outreach scholarship shifts the applied developmental scientist away from narrow and traditional notions of research subjects, patients, and clients to more appropriate notions of partners, consumers, and collaborators, there emerge areas as yet uncharted by the ethical standards of extant disciplines and professions. Indeed, even the imperativethat ethical behavior in ADS reflects some consensus or amalgam of the applied ethics embraced over time by diverse disciplines or traditions now teaming up in any of the areas of inquiry and action noted earlier-invokes challenge. Distinctive, perhaps even unique, ethical issues arise when the articulation of basic bioecological and contextual theories are parlayed into methods, measures, research designs, interventions, programs, and policies. Furthermore, whether in the 
traditional disciplines or in emergent ADS, ethical considerations are encumbered and enriched by the mores and pressures of the historical context. Thus, the particular exigencies of our evolving multicultural and global societies manifested in concerns about diversity and cultural sensitivity and competence become deep and abiding concerns for applied developmental scientists as they develop and test their theories, design and evaluate interventions, provide health or social services, or engage policymakers around social programs and policies.

As one example of the special ethical challenges that ADS must master, consider the research on early child care and education. As noted, the sociohistorical shift involving the entry of more women into the workforce has fueled the interest and concern of both society and developmental scientists. Hoffman (1990) describes the manner in which bias in the scientific process characterized much of the early research on maternal employment. Knowledge was produced and applied with an emphasis on documenting defects or deficits in children left in nonparental day care. As the more sophisticated concepts and methods of ADS were engaged to address social concerns over nonparental care, there were more nuanced and accurate notions of direct and indirect effects of individual differences and quality variables in home-based and center-based care settings. In addition, as dire as some of the ethical challenges were in the conduct of the science aimed at generating understanding about the impact of different care arrangements, the risks involved in the communication of findings to the public and to policymakers could also be harrow-ing and daunting. Hoffman (1990) concludes her account with the following position:

While there is a social responsibility to make findings available for social policy and individual decision, there is also a responsibility to communicate the results accurately and to educate the public about what the data can and cannot say. The tentative nature of our findings, their susceptibility to different interpretations, and the complications of translating them into individual or policy actions must be communicated to achieve an ethical science. (p. 268)

A second example to capture some of the particular ethical challenges facing ADS pertains especially to this particular historical moment in which ADS is gaining recognition as an "established discipline" (Fisher, Murray, \& Sigel, 1996, p. xvii). Training programs to produce the next generation of applied developmental scientists are only just emerging. Whereas some of the root or allied disciplines may have sophisticated quality control and credentialing procedures in place to increase the likelihood that ethical standards are met, ADS cannot borrow completely from these traditions. ADS must generate new and appropriate standards reflecting the exigencies of its special methods (e.g., outreach scholarship or universitycommunity partnerships) and the special expectations and demands faced by new applied developmental scientists as they pursue work in many, or any, of the domains of inquiry and action listed in Table 1.1.

For instance, traditional developmental psychologists can be trained and their allegiance to the ethical standards of the APA (1992) inculcated during their graduate training. Clinical psychologists, as another example, can be educated and held accountable both through their graduate training and professional careers in APA standards and in a variety of state and national licensing and credentialing conventions. Although applied developmental scientists now emerging from traditionally regulated fields, such as clinical, school, or counseling psychology, will have a starting point in these traditional ethical guidelines, neither they nor their colleagues from diverse disciplinary and multidisciplinary 
training bases are yet equipped with explicit ethical principles or credentials for the "practice" of ADS. Indeed, Koocher (1990) alerted the field to this challenge a decade ago, and though the sociopolitical scene has evolved in complex ways since then, the challenge remains for ADS to attend very seriously to issues of graduate training and ethics commensurate with its appropriately broadened scope and deepened mission.

\section{CONCLUSIONS}

A focus on person-context relations underscores the key implications of developmental systems models for research and application pertinent to promoting positive human development. At any given point in ontogenetic and historical time, neither individuals' attributes nor the features of their contexts (e.g., the demands of their parents regarding a temperamental style) per se are the foremost predictors of their healthy functioning. Instead, the relations between the child, the parent, the school, the community, and the other levels of organization within the developmental system are most important in understanding the character of human development and of the role of the ecology of human development in a person's ontogeny.

Essentially, the developmental systems model specifies that applied developmental scholarship pertinent to understanding and enhancing the life course should focus on the relational process of human development by longitudinally integrating the study of both the actions of the individual and the actions of parents, peers, teachers, neighbors, and the broader institutional context within which the individual is embedded. Bearing in mind the centrality of this complex relational system, the synthetic research and application agenda seems clear. Applied developmental scientists must continue to educate themselves about the best means available to promote (through integrating the developmental system) enhanced life chances among all individuals and families, but especially among those whose potential for positive contributions to civil society is most in danger of being wasted (Dryfoos, 1990, 1998; Hamburg, 1992; Lerner, 2002b; Lerner et al., 1999; Schorr, 1988, 1997).

The collaborative expertise of the research and program delivery communities can provide much of this information, especially if it is obtained in partnership with strong, empowered communities. Such coalitions could become integral components of an integrated child, family, and human development policy aimed at creating caring communities with the capacity to further the healthy development of children, adolescents, adults, and families (Jensen et al., 1999; Kennedy, 1999; Overton, B.J., \& Burkhardt, 1999; Sherrod, 1999b; Spanier, 1999; Thompson, 1999). Given the enormous and historically unprecedented challenges facing the youth and families of America and the world, there is no time to lose in the development of such collaborations if there is the aspiration to raise healthy and successful children capable of leading civil society productively, responsibly, and morally across the 21st century (Benson, 1997; Damon, 1997; Lerner, 1995; Lerner et al., 2000a, 2000b).

As was originally the case, the understanding of children, their development, and their needs is pursued only in part for the intellectual bounty. It is the use of this knowledge to enhance the quality of life for children that launched the discipline of developmental psychology in the late 19th century and propels ADS in the early 21st century. The field of human development has an opportunity through the publication of its ADS research to serve our world's citizens and demonstrate that there is nothing of greater value to civil society than a science devoted to using its scholarship to improve the life chances of all people. 


\section{REFERENCES}

Adams, M. J., Treiman, R., \& Pressley, M. (1998). Reading, writing, and literacy. In W. Damon (Series Ed.), I. E. Sigel \& K. A. Renninger (Vol. Eds.), Handbook of child psychology: Vol. 4. Child psychology in practice (5th ed., pp. 275356). New York: Wiley.

Adelman, H. S., \& Taylor, L. (2000). Looking at school health and school reform policy through the lens of addressing barriers to learning. Children's services: Social policy, research, and practice, 3(2), 117-132.

American Psychological Association. (1992). Ethical principles of psychologists and code of conduct. American Psychologist, 47(12), 1597-1611.

Baltes, P. B. (1987). Theoretical propositions of life-span developmental psychology: On the dynamics between growth and decline. Developmental Psychology, 23, 611-626.

Baltes, P. B., \& Baltes, M. M. (1980). Plasticity and variability in psychological aging: Methodological and theoretical issues. In G. E. Gurski (Ed.), Determining the effects of aging on the central nervous system (pp. 41-66). Berlin, Germany: Schering AG (Oraniendruck).

Baltes, P. B., Lindenberger, U., \& Staudinger, U. M. (1998). Life-span theory in developmental psychology. In W. Damon (Series Ed.) \& R. M. Lerner (Vol. Ed.), Handbook of child psychology: Vol. 1. Theoretical models of buman development (5th ed., pp. 1029-1144). New York: John Wiley.

Bearison, D. J. (1998). Pediatric psychology and children's medical problems. In W. Damon (Series Ed.), I. E. Sigel \& K. A. Renninger (Vol. Eds.), Handbook of child psychology: Vol. 4. Child psychology in practice (5th ed., pp. 635-712). New York: Wiley.

Benson, P. L. (1997). All kids are our kids: What communities must do to raise caring and responsible children and adolescents. San Francisco: Jossey-Bass.

Benson, P. L., Leffert, N., Scales, P. C., \& Blyth, D. A. (1998). Younger and older adults collaborating on retelling everyday stories. Applied Developmental Science, 2(3), 138-159.

Black, M. M., \& Krishnakumar, A. (1998). Children in low income, urban settings: Interventions to promote mental health and well-being. American Psychologist, 53, 635-646.

Boring, E. G. (1950). A history of experimental psychology (2nd ed.). New York: Appleton-Century-Crofts.

Bronfenbrenner, U. (1974). Developmental research, public policy, and the ecology of childhood. Child Development, 45, 1-5.

Bronfenbrenner, U., Kessel, F., Kessen, W., \& White, S. (1986). Toward a critical social history of developmental psychology. American Psychologist, 41(11), 1218-1230.

Bronfenbrenner, U., \& Morris, P. A. (1998). The ecology of developmental process. In W. Damon (Series Ed.) \& R. M. Lerner (Vol. Ed.), Handbook of child psychology: Vol. 1. Theoretical models of human development (5th ed., pp. 9931028). New York: Wiley.

Bruck, M., Ceci, S. J., \& Hembrooke, H. (1998). Reliability and credibility of young children's reports: From research to policy and practice. American Psychologist, 53(2), 136-151. 
Cairns, R. B. (1998). The making of developmental psychology. In W. Damon (Series Ed.) \& R. M. Lerner (Vol. Ed.), Handbook of child psychology: Vol. 1. Theoretical models of human development (5th ed., pp. 993-1028). New York: Wiley.

Cairns, R. B., Bergman, L. R., \& Kagan, J. (Eds.). (1998). Methods and models for studying the individual: Essays in honor of Marian Radke-Yarrow. Thousand Oaks, CA: Sage.

Chibucos, T., \& Lerner, R. M. (1999). Serving children and families through community-university partnerships: Success stories. Norwell, MA: Kluwer.

Cicchetti, D., \& Sroufe, L. A. (2000). The past as prologue to the future: The times, they've been a-changin'. [Editorial]. Development and Psychopathology, 12(3), 255-264.

Cicchetti, D., \& Toth, S. L. (1998a). The development of depression in children and adolescents. American Psychologist, 53(2), 221-243.

Cicchetti, D., \& Toth, S. L. (1998b). Perspectives on research and practice in developmental psychopathology. In W. Damon (Series Ed.), I. E. Sigel \& K. A. Renninger (Vol. Eds.), Handbook of child psychology: Vol. 4. Child psychology in practice (5th ed., pp. 479-484). New York: Wiley.

Coie, J. D., Watt, N. F., West, S. G., Hawkins, J. D., Asarnow, J. R., Markman, H. J., Ramey, S. L., Shure, M. B., \& Long, B. (1993). The science of prevention: A conceptual framework and some directions for a national research program. American Psychologist, 48(10), 1013-1022.

Coley, R. L., \& Chase-Lansdale, P. L. (1998). Adolescent pregnancy and parenthood: Recent evidence and future directions. American Psychologist, 53(2), 152-166.

Collins, W. A., Maccoby, E. E., Steinberg, L., Hetherington, E. M., \& Bornstein, M. H. (2000). Contemporary research on parenting: The case for nature and nurture. American Psychologist, 55(2), 218-232.

Cowan, P. A., Powell, D., \& Cowan, C. P. (1998). Parenting interventions: A family systems perspective. In W. Damon (Series Ed.), I. E. Sigel \& K. A. Renninger (Vol. Eds.), Handbook of child psychology: Vol. 4. Child psychology in practice (5th ed., pp. 3-72). New York: Wiley.

Csikszentmihalyi, M., \& Rathunde, K. (1998). The development of the person: An experiential perspective on the ontogenesis of psychological complexity. In W. Damon (Series Ed.) \& R. M. Lerner (Vol. Ed.), Handbook of child psychology: Vol. 1. Theoretical models of human development (5th ed., 635-684). New York: Wiley.

Damon, W. (1997). The youth charter: How communities can work together to raise standards for all our children. New York: Free Press.

Davisdon, E. S., \& Benjamin, L. T. Jr. (1987). A history of the child study movement in America. In J. A. Glover \& R. R. Ronning (Eds.), Historical foundations of educational psychology (pp. 41-60). New York: Plenum.

Dryfoos, J. G. (1990). Adolescents at risk: Prevalence and prevention. New York: Oxford University Press.

Dryfoos, J. G. (1998). Safe passage: Making it through adolescence in a risky society. New York: Oxford University Press.

Eccles, J. S., Lord, S., \& Buchanan, C. M. (1996). School transitions in early adolescence: What are we doing to your young people? In J. A. Graber, 
J. Brooks-Gunn, \& A. C. Petersen (Eds.), Transitions through adolescence (pp. 251-284). Mahwah, NJ: Lawrence Erlbaum.

Elkind, D. (2002). Early childhood education. In R. M. Lerner, F. Jacobs, \& D. Wertlieb (Eds.), Promoting positive child, adolescent, and family development. Thousand Oaks, CA: Sage. Manuscript in preparation.

Emery, R. E., \& Laumann-Billings, L. (1998). An overview of the nature, causes, and consequences of abusive family relationships: Toward differentiating maltreatment and violence. American Psychologist, 53(2), 121-135.

Fisher, C. B. (1997). A relational perspective on ethics-in-science decision making for research with vulnerable populations. IRB: A Review of Human Subjects Research, 19, 1-4.

Fisher, C. B., \& Brennan, M. (1992). Application and ethics in developmental psychology. In D. L. Featherman, R. M. Lerner, \& M. Perlmutter (Eds.), Life-span development and behavior (Vol. 11, pp. 189-219). Hillsdale, NJ: Lawrence Erlbaum.

Fisher, C. B., \& Lerner, R. M. (Eds.). (1994). Applied developmental psychology. New York: McGraw-Hill.

Fisher, C. B., \& Murray, J. P. (1996). Applied developmental science comes of age. In C. B. Fisher, J. P. Murray, \& I. E. Sigel (Eds.), Applied developmental science: Graduate training for diverse disciplines and educational settings (pp. 1-22). Norwood, NJ: Ablex.

Fisher, C. B., Murray, J. P., Dill, J. R., Hagen, J. W., Hogan, M. J., Lerner, R. M., Rebok, G. W., Sigel, I., Sostek, A. M., Spencer, M. B., \& Wilcox, B. (1993). The national conference on graduate education in the applications of developmental science across the lifespan. Journal of Applied Developmental Psychology, 14, 1-10.

Fisher, C. B., Murray, J. P., \& Sigel, I. E. (Eds.). (1996). Applied developmental science: Graduate training for diverse disciplines and educational settings. Norwood, NJ: Ablex.

Fisher, C. B., \& Tryon, W. W. (Eds.). (1990). Ethics in applied developmental psychology: Emerging issues in an emerging field (Vol. 4). Norwood, NJ: Ablex.

Fishman, D. B. (1999). The case for pragmatic psychology. New York: New York University Press.

Garner, W. R. (1972). The acquisition and application of knowledge: A symbiotic relation. American Psychologist, 27, 941-946.

Gollin, E. S. (1981). Development and plasticity. In E. S. Gollin (Ed.), Developmental plasticity: Behavioral and biological aspects of variations in development (pp. 231-251). New York: Academic Press.

Gottlieb, G. (1992). Individual development and evolution: The genesis of novel behavior. New York: Oxford University Press.

Hagen, J. W. (1996). Graduate education in the applied developmental sciences: History and background. In C. B. Fisher \& J. P. Murray (Eds.), Applied developmental science: Graduate training for diverse disciplines and educational settings, advances in applied developmental psychology. (pp. 45-51). Norwood, NJ: Ablex.

Hamburg, D. A. (1992). Today's children: Creating a future for a generation in crisis. New York: Times Books.

Hamburger, V. (1957). The concept of development in biology. In D. B. Harris (Ed.), The concept of development (pp. 49-58). Minneapolis: University of Minnesota Press. 
Hamilton, S. F., \& Hamilton, M. (1999). Creating new pathways to adulthood by adapting German apprenticeship in the United States. In W. R. Heinz (Ed.), From education to work: Cross-national perspectives (pp. 194-213). New York: Cambridge University Press.

Hernandez, D. J. (1993). America's children: Resources for family, government, and the economy. New York: Russell Sage.

Hetherington, E. M. (1998). Relevant issues in developmental science: Introduction to the special issue. American Psychologist, 53(2), 93-94.

Hetherington, E. M., Bridges, M., \& Insabella, G. M. (1998). What matters? What does not? Five perspectives on the association between marital transitions and children's adjustment. American Psychologist, 53(2), 167-184.

Higgins-D'Alessandro, A., Fisher, C. B., \& Hamilton, M. G. (1998). Educating the applied developmental psychologist for university-community partnerships. In R. M. Lerner \& L. A. K. Simon (Eds.), University-community collaborations for the twenty-first century: Outreach scholarship for youth and families (pp. 157-183). New York: Garland.

Hoffman, L. W. (1990). Bias and social responsibility in the study of maternal employment. In C. B. Fisher \& W. W. Tyron (Eds.), Ethics in applied developmental psychology: Emerging issues in an emerging field. (Vol. 4, pp. 253-272). Norwood, NJ: Ablex.

Horowitz, F. D. (2000). Child development and the PITS: Simple questions, complex answers, and developmental theory. Child Development, 71, 1-10, 8,58 .

Horowitz, F. D., \& O'Brien, M. (1989). In the interest of the nature: A reflective essay on the state of our knowledge and challenges before us. American Psychologist, 44, 441-445.

Huston, A. C. (Ed.). (1991). Children in poverty: Child development and public policy. Cambridge, UK: Cambridge University Press.

Huston, A. C., McLoyd, V. C., \& Garcia Coll, C. (1994). Children and poverty: Issues in contemporary research. Child Development, 65, 275-282.

Huston, A. C., \& Wright, J. C. (1998). Mass media and children's development. In W. Damon (Series Ed.), I. E. Sigel \& K. A. Renninger (Vol. Eds.), Handbook of child psychology: Vol. 4. Child psychology in practice (5th ed., pp. 999-1058). New York: Wiley.

Jensen, P., Hoagwood, K., \& Trickett, E. (1999). Ivory towers or earthen trenches? Community collaborations to foster "real world" research. Applied Developmental Science, 3(4), 206-212.

Kaplan, R. M. (2000). Two pathways to prevention. American Psychologist, 55(4), 382-396.

Kellogg Commission on the Future of State and Land-Grant Colleges. (1999). Returning to our roots: The engaged institution. Washington, DC: National Association of State Universities and Land-Grant Colleges.

Kennedy, E. M. (1999). University-community partnerships: A mutually beneficial effort to aid community development and improve academic learning opportunities. Applied Developmental Science, 3(4), 197-198.

Koch, S., \& Leary, D. E. (Eds.). (1985). A century of psychology as science. New York: McGraw-Hill.

Koocher, G. P. (1990). Practicing applied developmental psychology: Playing the game you can't win. In I. E. Sigel (Ed.), Ethics in applied developmental 
psychology: Emerging issues in an emerging field (pp. 215-225). Norwood, NJ: Ablex.

Kuo, Z. Y. (1930). The genesis of the cat's response to the rat. Journal of Comparative Psychology, 11, 1-35.

Kuo, Z. Y. (1967). The dynamics of behavior development. New York: Random House.

Kuo, Z. Y. (1976). The dynamics of behavior development: An epigenetic view. New York: Plenum.

Lamb, M. E. (1998). Children in poverty: Development, public policy, and practice. In W. Damon (Series Ed.), I. E. Sigel \& K. A. Renninger (Vol. Eds.), Handbook of child psychology: Vol. 4. Child psychology in practice (5th ed., pp. 73-134). New York: Wiley.

Leffert, N., Benson, P. L., Scales, P. C., Sharma, A. R., Drake, D. R., \& Blyth, D. A. (1998). Developmental assets: Measurement and prediction of risk behaviors among adolescents. Applied Developmental Science, 2(4), 209-230.

Lerner, R. M. (1976). Concepts and theories of human development. Reading, MA: Addison-Wesley.

Lerner, R. M. (1984). On the nature of human plasticity. New York: Cambridge University Press.

Lerner, R. M. (1986). Concepts and theories of human development (2nd ed.). New York: Random House.

Lerner, R. M. (1995). America's youth in crisis: Challenges and options for programs and policies. Thousand Oaks, CA: Sage.

Lerner, R. M. (Ed.). (1998a). Handbook of child psychology: Vol. 1. Theoretical models of human development (5th ed.). New York: Wiley.

Lerner, R. M. (1998b). Theories of human development: Contemporary perspectives. In W. Damon (Series Ed.) \& R. M. Lerner (Vol. Ed.), Handbook of child psychology: Vol. 1. Theoretical models of human development (5th ed., pp. 1-24). New York: John Wiley.

Lerner, R. M. (2002a). Adolescence: Development, diversity, context, and application. Upper Saddle River, NJ: Prentice Hall.

Lerner, R. M. (2002b). Concepts and theories of human development (3rd ed.). Mahwah, NJ: Lawrence Erlbaum.

Lerner, R. M., \& Fisher, C. B. (1994). From applied developmental psychology to applied developmental science: Community coalitions and collaborative careers. In C. B. Fisher \& R. M. Lerner (Eds.), Applied developmental psychology (pp. 502-522). New York: McGraw-Hill

Lerner, R. M., Fisher, C. B., \& Weinberg, R. A. (1997). Applied developmental science: Scholarship for our times. Applied Developmental Science, 1(1), 2-3.

Lerner, R. M., Fisher, C. B., \& Weinberg, R. A. (2000a). Applying developmental science in the twenty-first century: International scholarship for our times. International Journal of Behavioral Development, 24, 24-29.

Lerner, R. M., Fisher, C. B., \& Weinberg, R. A. (2000b). Toward a science for and of the people: Promoting civil society through the application of developmental science. Child Development, 71(1), 11-20.

Lerner, R. M., \& Galambos, N. (1998). Adolescent development: Challenges and opportunities for research, programs, and policies. In J. T. Spence (Ed.), Annual Review of Psychology (Vol. 49, pp. 413-446). Palo Alto, CA: Annual Reviews. 
Lerner, R. M., \& Miller, J. R. (1998). Developing multidisciplinary institutes to enhance the lives of individuals and families: Academic potentials and pitfalls. Journal of Public Service and Outreach, 3(1).

Lerner, R. M., Miller, J. R., Knott, J. H., Corey, K. E., Bynum, T. S., Hoopfer, L. C., McKinney, M. H., Abrams, L. A., Hula, R. C., \& Terry, P. A. (1994). Integrating scholarship and outreach in human development research, policy, and service: A developmental contextual perspective. In D. L. Featherman, R. M. Lerner, \& M. Perlmutter (Eds.), Life-span development and behavior (Vol. 12, pp. 249-273). Hillsdale, NJ: Lawrence Erlbaum.

Lerner, R. M., Ostrom, C. W., \& Freel, M. A. (1995). Promoting positive youth and community development through outreach scholarship: Comments on Zeldin and Peterson. Journal of Adolescent Research, 10, 486-502.

Lerner, R. M., \& Ryff, C. (1978). Implementation of the life-span view of human development: The sample case of attachment. In P. B. Baltes (Ed.), Life-span development and behavior (Vol. 1, pp. 1-44). New York: Academic Press.

Lerner, R. M., \& Simon, L. A. K. (1998a). Directions for the American outreach university in the twenty-first century. In R. M. Lerner \& L. A. K. Simon (Eds.), University-community collaborations for the twenty-first century: Outreach scholarship for youth and families (pp. 463-481). New York: Garland.

Lerner, R. M., \& Simon, L. A. K. (1998b). The new American outreach university: Challenges and options. In R. M. Lerner \& L. A. K. Simon (Eds.), Universitycommunity collaborations for the twenty-first century: Outreach scholarship for youth and families (pp. 3-23). New York: Garland.

Lerner, R. M., Sparks, E. S., \& McCubbin, L. (1999). Family diversity and family policy: Strengthening families for America's children. Norwell, MA: Kluwer.

Little, R. R. (1993). What's working for today's youth: The issues, the programs, and the learnings. Paper presented at the ICYF Fellows Colloquium, Michigan State University, East Lansing.

Loeber, R., \& Stouthamer-Loeber, M. (1998). Development of juvenile aggression and violence: Some common misconceptions and controversies. American Psychologist, 53(2), 242-259.

Lorenz, K. (1966). On aggression. New York: Harcourt, Brace \& World.

Martland, N., \& Rothbaum, F. (1999). Cameo feature news: University and community partnership disseminates child development information. In T. R. Chibucos \& R. M. Lerner (Eds.), Serving children and families through community-university partnerships: Success stories (pp. 173-180). Boston: Kluwer.

Masten, A. S., \& Coatsworth, J. D. (1998). The development of competence in favorable and unfavorable environments: Lessons from research on successful children. American Psychologist, 53(2), 205-220.

McCall, R., \& Groark, C. (2000). The future of applied child development research and public policy. Child Development, 71, 197-204.

McCall, R. B. (1996). The concept and practice of education, research, and public service in university psychology departments. American Psychologist, 51(4), 379-388.

McCall, R. B., Groark, C. J., Strauss, M. S., \& Johnson, C. N. (1995). The University of Pittsburgh office of child development: An experiment in promoting interdisciplinary applied human development. Journal of Applied Developmental Psychology, 16, 593-612. 
McLoyd, V. C. (1998). Socioeconomic disadvantage and child development. American Psychologist, 53(2), 185-204.

Meszaros, P. S. (2003). Family and consumer sciences: A holistic approach stretching to the future. In R. M. Lerner, F. Jacobs, D. Wertlieb, \& F. Jacobs (Eds.), Handbook of applied developmental science: Vol. 4. Adding value to youth and family development: The engaged university and professional and academic outreach. Thousand Oaks, CA: Sage.

Morrison, F. J., Lord, C., \& Keating, D. P. (1984). Applied developmental psychology. In F. J. Morrison, C. Lord, \& D. P. Keating (Eds.), Applied developmental psychology (Vol. 1, pp. 4-20). New York: Academic Press.

Mussen, P. H. (Ed.). (1970). Carmichael's manual of child psychology (3rd ed.). New York: Wiley.

Nickols, S. Y. (2002). Family and consumer sciences in the United States. In N. J. Smelser \& P. B. Baltes (Eds.), International encyclopedia of the social and behavioral sciences. Oxford, UK: Elsevier.

Ostrom, C. W., Lerner, R. M., \& Freel, M. A. (1995). Building the capacity of youth and families through university-community collaborations: The development-incontext evaluation (DICE) model. Journal of Adolescent Research, 10(4), 427-448.

Overton, B. J., \& Burkhardt, J. C. (1999). Drucker could be right, but . . . : New leadership models for institutional-community partnerships. Applied Developmental Science, 3(4), 217-227.

Overton, W. (1998). Developmental psychology: Philosophy, concepts, and methodology. In W. Damon (Series Ed.) \& R. M. Lerner (Ed.), Handbook of child psychology: Vol. 1. Theoretical models of human development (5th ed., pp. 107-187). New York: Wiley.

Parke, R. D., Ornstein, P. A., Reiser, J. J., \& Zahn-Waxler, C. (Eds.). (1994). A century of developmental psychology. Washington, DC: American Psychological Association.

Pepper, S. C. (1942). World hypotheses: A study in evidence. Berkeley: University of California Press.

Pittman, K. (1996, Winter). Community, youth, development: Three goals in search of connection. New Designs for Youth Development, pp. 4-8.

Plomin, R. (1986). Development, genetics, and psychology. Hillsdale, NJ: Lawrence Erlbaum.

Plomin, R. (2000). Behavioural genetics in the 21st century. International Journal of Behavioral Development, 24, 30-34.

Plomin, R., Corley, R., DeFries, J. C., \& Faulker, D. W. (1990). Individual differences in television viewing in early childhood: Nature as well as nurture. Psychological Science, 1, 371-377.

Power, F. C., Higgins, A., \& Kohlberg, L. (1989). Lawrence Kohlberg's approach to moral education. New York: Columbia University Press.

Ramey, C. T., \& Ramey, S. L. (1998). Early intervention and early experience. American Psychologist, 53(2), 109-120.

Renninger, K. A. (1998). Developmental psychology and instruction: Issues from and for practice. In W. Damon (Series Ed.), I. E. Sigel \& K. A. Renninger (Vol. Eds.), Handbook of child psychology: Vol. 4. Child psychology in practice (5th ed., pp. 211-274). New York: Wiley.

Richters, J. E. (1997). The Hubble hypothesis and the developmentalist's dilemma. Development and Psychopathology, 9, 193-229. 
Rowe, D. (1994). The limits of family influence: Genes, experience, and behavior. New York: Guilford.

Rushton, J. P. (1987). An evolutionary theory of health, longevity, and personality: Sociobiology, and $\mathrm{r} / \mathrm{K}$ reproductive strategies. Psychological Reports, 60, 539-549.

Rushton, J. P. (1988a). Do r/K reproductive strategies apply to human differences? Social Biology, 35, 337-340.

Rushton, J. P. (1988b). Race differences in behavior: A review and evolutionary analysis. Personality and Individual Differences, 9, 1009-1024.

Rushton, J. P. (1997). More on political correctness and race differences. Journal of Social Distress and the Homeless, 6, 195-198.

Rushton, J. P. (1999). Race, evolution, and behavior (Special abridged ed.). New Brunswick, NJ: Transaction Publishing.

Rushton, J. P. (2000). Race, evolution, and behavior (2nd special abridged ed.). New Brunswick, NJ: Transaction Publishing.

Rutter, M., \& Sroufe, L. A. (2000). Developmental psychopathology: Concepts and challenges. Development and Psychopathology, 12(3), 265-296.

Scales, P. C., Benson, P. L., Leffert, N., \& Blyth, D. A. (2000). Contribution of developmental assets to the prediction of thriving among adolescents. Applied Developmental Science, 4(1), 27-46.

Scales, P. C., \& Leffert, N. (1999). Developmental assets: A synthesis of the scientific research on adolescent development. Minneapolis, MN: Search Institute.

Scarr, S. (1998). American child care today. American Psychologist, 53(2), 95-108.

Schneirla, T. C. (1956). Interrelationships of the innate and the acquired in instinctive behavior. In P. P. Grassé (Ed.), L'instinct dans le comportement des animaux et de l'homme. Paris: Mason et Cie.

Schneirla, T. C. (1957). The concept of development in comparative psychology. In D. B. Harris (Ed.), The concept of development: An issue in the study of human behavior (pp. 78-108). Minneapolis: University of Minnesota Press.

Schorr, L. B. (1988). Within our reach: Breaking the cycle of disadvantage. New York: Doubleday.

Schorr, L. B. (1997). Common purpose: Strengthening families and neighborhoods to rebuild America. New York: Doubleday.

Schwebel, D. C., Plumert, J. M., \& Pick, H. L. (2000). Integrating basic and applied developmental research: A new model for the twenty-first century. Child Development, 71(1), 222-230.

Sears, R. R. (1975). Your ancients revisited: A history of child development. In E. M. Hetherington (Ed.), Review of child development research (Vol. 6, pp. 1-73). Chicago: University of Chicago Press.

Sherrod, L. R. (1999a). Funding opportunities for applied developmental science. In P. Ralston, R. M. Lerner, A. K. Mullis, C. Simerly, \& J. Murray (Eds.), Social change, public policy, and community collaboration: Training human development professionals for the twenty-first century (pp. 121-129). Norwell, MA: Kluwer.

Sherrod, L. R. (1999b). "Giving child development knowledge away": Using university-community partnerships to disseminate research on children, youth, and families. Applied Developmental Science, 3(4), 228-234.

Shonkoff, J. (2000). Science, policy, and practice: Three cultures in search of a shared mission. Child Development, 71, 181-187. 
Siegel, A. W., \& White, S. H. (1982). The child study movement: Early growth and development of the symbolized child. In H. W. Reese (Ed.), Advances in child development and behavior (Vol. 17, pp. 233-285). New York: Academic Press.

Sigel, I. E. (1985). Parental belief systems: The psychological consequences for children. Hillsdale, NJ: Lawrence Erlbaum.

Sigel, I. E., \& Cocking, R. R. (1980). Editors' message. Journal of Applied Developmental Psychology, 1(1), i-iii.

Sigel, I. E., \& Renninger, K. A. (Eds.). (1998). Handbook of child psychology: Vol. 4. Child psychology in practice (5th ed.). New York: John Wiley.

Spanier, G. B. (1999). Enhancing the quality of life: A model for the 21st century land-grant university. Applied Developmental Science, 3(4), 199-205.

Strauss, S. (1998). Cognitive development and science education: Toward a middle level model. In W. Damon (Series Ed.), I. E. Sigel \& K. A. Renninger (Vol. Eds.), Handbook of child psychology: Vol. 4. Child psychology in practice (5th ed., pp. 357-400). New York: Wiley.

Takanishi, R. (1993). An agenda for the integration of research and policy during early adolescence. In R. M. Lerner (Ed.), Early adolescence: Perspectives on research, policy, and intervention (pp. 457-470). Hillsdale, NJ: Lawrence Erlbaum.

Thompson, L. (1999). Creating partnerships with government, communities, and universities to achieve results for children. Applied Developmental Science, 3(4), 213-216.

Tobach, E. (1994). Personal is political is personal is political. Journal of Social Issues, 50, 221-224.

Trickett, E. J., Barone, C., \& Buchanan, R. M. (1996). Elaborating developmental contextualism in adolescent research and intervention: Paradigm contributions from community psychology. Journal of Research on Adolescence, 6(3), 245-269.

Valsiner, J. (1998). The development of the concept of development: Historical and epistemological perspectives. In W. Damon (Series Ed.) \& R. M. Lerner (Vol. Ed.), Handbook of child psychology: Vol. 1. Theoretical models of human development (5th ed., pp. 189-232). New York: Wiley.

von Bertalanffy, L. (1933). Modern theories of development. London: Oxford University Press.

Weissberg, R. P., \& Greenberg, M. T. (1998). School and community competenceenhancement and prevention programs. In W. Damon (Series Ed.), I. E. Sigel \& K. A. Renninger (Vol. Eds.), Handbook of child psychology: Vol. 4. Child psychology in practice (5th ed., pp. 877-954). New York: Wiley.

Wertlieb, D. (2001). Converging trends in family research and pediatrics: Recent findings for the AAP task force on the family. Unpublished manuscript.

Wertlieb, D. (2003). Applied developmental science. In I. B. Weiner (Series Ed.), R. M. Lerner, M. A. Easterbrooks, \& J. Mistry (Vol. Eds.), Handbook of psychology: Vol. 6. Developmental psychology. New York: Wiley.

Wertlieb, D. L. (1997). Children whose parents divorce: Life trajectories and turning points. In I. Gotlieb \& B. Wheaton (Eds.), Stress and adversity over the life course: Trajectories and turning points (pp. 179-196). Cambridge, UK: Cambridge University Press.

White, S. H. (1992). G. Stanley Hall: From philosophy to developmental psychology. Developmental Psychology, 28, 25-34. 
Zigler, E. (1980). Welcoming a new journal. Journal of Applied Developmental Psychology, 1(1), 1-6.

Zigler, E. (1998). A place of value for applied and policy studies. Child Development, 69(2), 532-542.

Zigler, E., \& Finn-Stevenson, M. (1992). Applied developmental psychology. In M. H. Bornstein \& M. E. Lamb (Eds.), Developmental psychology: An advanced textbook (3rd ed., pp. 677-729). Hillsdale, NJ: Lawrence Erlbaum.

Zigler, E. F., \& Finn-Stevenson, M. (1999). Applied developmental psychology. In M. H. Bornstein \& M. E. Lamb (Eds.), Developmental psychology: An advanced textbook (4th ed.). Mahwah, NJ: Lawrence Erlbaum. 
01-Lerner (ADS).qxd 12/14/2004 8:24 PM Page 30 